\section{Cover Picture}

Kalvak is one of the first at Holman Island to use colour. In her stone cut portrayed on the cover of this issue, the sea monsters are prirted in a rich yellow-green. The x-ray views indicate that these creatures devour men, seals, birds, and fish - all beautifully simplified in their miniature form.

Kalvak, a great-grandmother approaching seventy, did not begin to draw until she was past sixty. The design, seen out of context, could indicate youth rather than age.

\section{Report on the Field Work of the Polish Spitsbergen Expedition, Summer 1970}

With the support of the Commission of Geophysical Expeditions of the Polish Academy of Sciences and in collaboration with the Geophysical Department of the Polish Academy of Sciences the Geographical Institute of the University of Wroclaw organized in 1970 a scientific summer expedition to Spitsbergen. It operated in the Hornsund Fiord region where previous Polish investigations (1957-1962) had been carried out.

The expedition's principal aims were to make detailed glaciological and geomorphological studies in the Hornsund region in connection with previous research. At the same time the expedition members carried out repairs and maintenance work of the installation and equipment within the premises of the Polish Station in Hornsund. The station, established in 1957 , had seldom been visited by Poles since 1962. The Norsk Polarinstitutt, Oslo, had been informed about the research program of the expedition.

The expedition left Gdynia on 15 June on board the Marine High School Training Ship S/T Jan Turlejski, and after 13 days of voyage, with a one-day visit in Troms $\varnothing$, it reached Hornsund. The landing conditions were exceptionally difficult. A strong east wind drifted great amounts of sea-ice and pieces of glacier icebergs to the bay of the Polar Bear (Isbiørnhamna). The unloading of people and equipment had to be done with the high wave surf at the very base of the Hans Glacier. From there the expedition had to transport all the luggage to the base 1 kilometre distant. The 6 members of the expedition stayed from 28 June until 12 September on Spitsbergen and returned to Gdynia on 26 September. On the way back they and the ship's crew paid a brief two-hour visit to the crew of the radio- and meteorological-station on Bear Island (Bjørnøya). They also visited Narvik and together with a group of Polish combatants of the battle of Narvik they decorated the graves of Polish soldiers with flowers.

The main part of the expedition research was concerned with glaciological, geomorphological and to some extent geophysical work performed on the Werenskiold Glacier (which terminates on land) and on the Hans Glacier (which flows into the fiord) and in their immediate vicinity. To check the quality of the various measuring instruments, numerous tests were made especially with electric meters.

The glaciological program, prepared by the leader of the expedition, was carried out chiefly on the Werenskiold and Hans Glaciers. The work included: climatological and glacio-meteorological research, glaciological investigations, hydrological and hydrographical measurements and observations, and glaciomorphological and geomorphological research.

The principal purpose of the climatological and glacio-meteorological investigations was to establish how climatic conditions arise on the periglacial tundra in the Hornsund Base vicinity, and on the Werenskiold Glacier and vicinity. These investigations were connected with climatic research in that region and in reference to contemporary observations made at Norwegian stations in the centre of Spitsbergen. Microclimatic studies of the tundra and glaciers seem to be particularly important, since climatic conditions exert an undoubted (though not yet fully known) influence on the glacial and morphological features and on the vegetation of the region. Because of the close link between the process of glacier ablation and the energetic processes in the atmosphere, special attention was given to the study of the course of the parameters of radiation and heat balances in the ground air layer. The expedition made it a rule to take maximum advantage of continuous automatic recording of the above-mentioned balances and weather elements.

The quickly retreating Werenskiold Glacier snout creates particularly favourable conditions for glacio-morphological and geomorphological studies mainly because of the abundance of the freshly uncovered forms and due to a great diversity of geomorphic problems.

The main aim of these investigations in the 1970 season was to mark the character of changes on the map of the marginal zone of the Werenskiold Glacier in the scale 1:7,500. 
This was possible with the help of 70 painted stone cairns installed in the glacier forefield, their positions and altitudes being measured with theodolite and altimeter. Photographic pictures were very useful in this respect.

At the Arie Glacier forefield detailed geomorphological and geological studies were undertaken which resulted in constructing a map of the region in the scale $1: 10,000$. Besides making several pits and exposures, ten rock and morainic samples were taken from the region for laboratory examination.

The process of dead ice ablation under the morainic cover and without it and the process of melting-out and translocation of the rock surface material on the distal slopes of the Hans Glacier lateral moraine underwent careful observation and measurements. For comparison the ablation of the active part of the Hans Glacier near its end was measured. Five samples were taken for further analysis in Poland.

Observations and measurements regarding the development and distribution of the block covers on the ridges of the Fugleberget, Ariekammen, Skodefjellet and Rotjesfiellet mountains were also made as well as observations of rock forms on raised sea beaches in the vicinity of the Hornsund Base.

The geophysical investigations concerned glaciological problems to a considerable degree. The natural tremors of the Hans Glacier were studied on the basis of microseismographic recordings taken with the help of a vertical seismograph.

Apart from their research work the expedition members collected many specimens of rock and took photographs for didactic purposes.

The expenses connected with the stay of the expedition on Spitsbergen were covered by the Wroclaw University (food for 5 persons, medicine, the main part of the equipment, instruments, material and fuel), and by the Geophysical Department of the Polish Academy of Sciences (food and equipment for 1 person). For the first time in the history of Polish expeditions certain amounts of sauerkraut and apples had been taken which preserved very well over the larger part of the summer and were welcomed by the expedition members. To a considerable degree the equipment and the instruments that had been used in previous Spitsbergen expeditions were still available. Some of the equipment was borrowed.

It is expected that the publication of the material and the results of the expedition will appear in English (with Polish summaries) in one of the volumes of Geograph- ical Studies of the "Acta Universitatis Wratislaviensis".

Since this summary report was written, the Geographical Institute of the University of Wroclaw sent another expedition to Spitsbergen, in the summer of 1971. The report on that expedition with some preliminary results of the work done during the two summers will appear in a future issue of Arctic.

There are certain grounds for expecting that after the successful series of expeditions in the years $1957-1962$ the 1970 and 1971 expeditions were the first of a new series of four or five Polish expeditions that will be sent to Spitsbergen in coming years.

\section{S. Baranowski \\ University of Wroclaw \\ Leader of the Expedition}

\section{Note on the \\ No-stress Boundary Condition at the Edge of the Ice Pack}

The theoretical modelling of the large-scale motion of the arctic ice pack is receiving increasing attention as the economic importance of the region increases. One of the most widely used types of model is the socalled "viscous fluid" model. The early development of such models has been described by Campbell ${ }^{1}$. Recent developments are described by Doronin ${ }^{2}$, and by numerous authors in the AIDJEX Bulletin ${ }^{3}$.

The boundary condition at the edge of the ice pack is an important feature of most such models. In some cases a no-slip condition seems appropriate, but in others, when the ice near the boundary has a low compactness (fraction of ice coverage) or the boundary occurs away from a coast, some other condition may be more appropriate. One that is often suggested is a no-stress condition, which is often assumed to imply that there is no velocity gradient perpendicular to the boundary. When the edge occurs away from a coast, the latter assumption is wrong.

It suffices for present purposes to assume that we are dealing with an incompressible two-dimensional fluid. In this case the viscous force per unit of area (corresponding to volume in three dimensions) is $\nabla \cdot(A \nabla \vec{v})$, where $A$ is an isotropic but possibly variable coefficient of eddy viscosity, and $\vec{v}$, the largescale averaged horizontal ice velocity, has components $u$ and $v$ in the $x$ and $y$ directions respectively. The notation $\nabla \vec{v}$, as used by Morse and Feshbach ${ }^{4: 65}$ is equivalent to the tensor $\left[\partial \mathrm{v}_{\mathrm{i}} / \partial \mathrm{x}_{\mathrm{j}}\right]$, where $\mathrm{i}$ and $\mathrm{j}$ vary inde- 